\title{
Grassland fire effect on soil organic carbon reservoirs in a semiarid environment
}

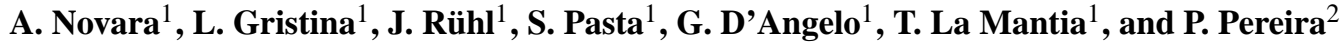 \\ ${ }^{1}$ Dipartimento di Scienze agrarie e forestali, University of Palermo, 90128 Palermo, Italy \\ ${ }^{2}$ Environmental Research Centre, Mykolas Romeris University, Ateities g. 20, 08303 Vilnius, Lithuania
}

Correspondence to: A. Novara (agata.novara@unipa.it)

Received: 18 April 2013 - Published in Solid Earth Discuss.: 3 July 2013

Revised: 23 September 2013 - Accepted: 30 September 2013 - Published: 29 October 2013

\begin{abstract}
The aim of this work was to investigate the effect of an experimental fire used for grassland management on soil organic carbon (SOC) stocks. The study was carried out on Hyparrhenia hirta (L.) Stapf $(H h)$ grassland and Ampelodesmos mauritanicus (Desf.) T. Durand \& Schinz (Am) grasslands located in the north of Sicily. Soil samples were collected at $0-5 \mathrm{~cm}$ before and after the experimental fire, and SOC was measured. During the grassland fire, soil surface temperature was monitored. Biomass of both grasses was analysed in order to determine dry weight and its chemical composition. The results showed that SOC varied significantly with vegetation type, while it is not affected in the short term by grassland fire. Am grassland stored more SOC compared with $H h$ grassland thanks to lower content in the biomass of the labile carbon pool. No significant difference was observed in SOC before and after fire, which could be caused by several factors: first, in both grassland types the measured soil temperature during fire was low due to thin litter layers; second, in a semiarid environment, a higher mineralization rate results in a lower soil carbon labile pool; and third, the SOC stored in the finest soil fractions, physically protected, is not affected by fire.
\end{abstract}

\section{Introduction}

Grasslands play an important role in geomorphological processes (controlling runoff and sediment dynamics) and ecosystem stability (Kocyigita and Demirc, 2012; Mukhopadhyay and Maiti, 2013; Yu et al., 2013; Kukal and Bawa, 2013). Fire is part of the Earth system and has for mil- lennia been a tool for many societies (Pyne, 2001), and this is well-known in grasslands (Dickie and Parson, 2012).

Fire is regarded as an active ecological agent able to mobilize nutrients and restore soil fertility (Snyman, 2003), but also as a primary cause of soil degradation due to nutrient loss for volatilization, leaching and erosion, especially in severe wildfires. It is, in fact, considered a major disturbance in many ecosystems which leads to important shifts in soil properties and vegetation (Certini, 2005; Granged et al., 2011a). One of the most common effects of fire is the alteration in the composition and amount of soil organic matter (Knicker, 2007; Terefe et al., 2008). Several studies recorded a decrease (Fernández et al., 1997; Novara et al., 2011) in soil organic carbon (SOC) after fire, while results of other studies showed no significant change or even an increase in previous SOC content (Kavdir et al., 2005). These discrepancies occur due to the large amount of controlling factors, and therefore the effect of fire is highly variable in space and time. Among these factors, fire intensity, fire severity, fire regimen, type of burned vegetation, connectivity, distribution of fuel on the soil surface, type of ash produced and dispersion, topography, soil properties, aspect, regional climate and meteorological conditions in the immediate period after the fire play a key role in determining SOC alteration and accumulation in soils (Certini, 2005; Pereira et al., 2010, 2013).

In semiarid areas fire is one of the common management tools used by shepherds to enhance pasture regrowth, and this is found in many other grass-covered soils on the Earth, at any latitude (Wang et al., 2005; Li et al., 2012; Busso et al., 2012). In fact, the recovery of vegetation canopy after fire in the Mediterranean area can be quite rapid due to adaption of plant communities to the disturbances caused by fire, 
as observed in several studies (Trabaud, 1981; Oba, 1990; Woube, 1998; Barberis et al., 2003; Pausas and Verdú 2005). It is known, moreover, that fire is considered an important factor for arid and semiarid grasslands because it avoids invasion of trees and shrubs, with implications for soil carbon storage (Briggs et al., 2005). Despite the importance of fire for grassland ecosystems (Bond et al., 2005), its impact on SOC is not well understood in the immediate period after the fire in the Mediterranean grasslands (Snyman, 2003). The aim of this work is to quantify SOC stock change as a result of an experimental fire to two of the most widespread types of Mediterranean grassland (Brullo et al., 2010; Díez-Garretas and Asensi, 1999) and, therefore, to establish if this practice could be used as a sustainable management tool for grazing recovery (Álvarez-Martínez et al., 2013).

\section{Materials and methods}

The field studies were carried out in the province of Palermo, Sicily (Italy, $350 \mathrm{~m}$ a.s.1.; Fig. 1). The local soil type is a $\mathrm{Eu}$ tric Cambisol according to WRB (WRB, 2006), with sand and clay contents of $18 \%$ and $46 \%$, respectively. The climate is Mediterranean, with mean annual rainfall of $580 \mathrm{~mm}$ and yearly average temperature of $16^{\circ} \mathrm{C}$.

An experimental fire was conducted in July and September 2009 on five (replica) delimited square areas $(50 \times 50 \mathrm{~cm})$ in two different grassland types, dominated by Hyparrhenia hirta (L.) Stapf $(\mathrm{Hh})$ and Ampelodesmos mauritanicus (Desf.) T. Durand \& Schinz (Am). Each sampling square was about $2 \mathrm{~m}$ distant from the neighbouring square. In order to simulate a natural wildfire, burning was allowed to take its natural course until it extinguished itself. The fire was generated with a match, starting from leeward in each plot. Soil surface temperature during the burning was measured using a thermocouple system (type K Inconel 600 insulated). In each selected area three soil samples were collected at 0 $5 \mathrm{~cm}$ depth before and immediately after the fire. On three one-metre squares in both grasslands (dominated by Hyparrhenia hirta or Ampelodesmos mauritanicus) all plants were cut, oven-dried for 3-4 days at $60-65^{\circ} \mathrm{C}$, and weighted. SOC content was measured using a $\mathrm{CHN}$ elemental analyzer. For the $\delta^{13} \mathrm{C}$ analysis, EA-IRMS (elemental analyzer isotope ratio mass spectrometry) was used. The International Atomic Energy Agency (IAEA), Vienna, distributes IAEA-CH-6 as standard reference material. The results of the isotope analysis are expressed as a $\delta$ value (\%o) relative to the international Pee Dee Belemnite standard as follows:

$\delta(\% o)=\frac{R_{\mathrm{S}}-R_{\mathrm{st}}}{R_{\mathrm{st}}} \times 1000$,

where $\delta=\delta{ }^{13} \mathrm{C}, R={ }^{13} \mathrm{C} /{ }^{12} \mathrm{C}$, $\mathrm{s}=$ sample and st $=$ standard.

Dry biomass weight and its chemical composition (ADF acid detergent fibre, NDF neutral detergent fibre, cellulose,

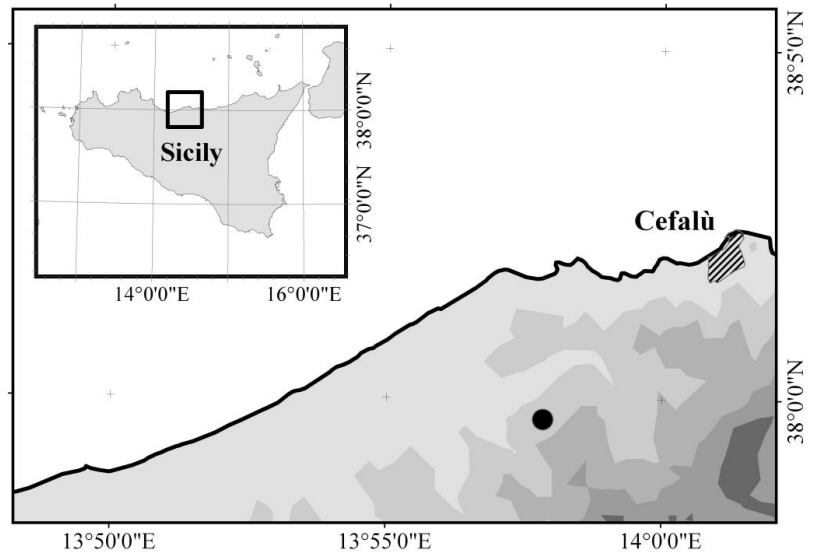

Fig. 1. Localization of the study area (black point) in Sicily (rectangle in inset) and with respect to the next urban settlement Cefalù. Grey scale represents altitudinal gradient ( 1 shade of grey $=200 \mathrm{~m}$ ).

hemicellulose, lignin, ash) were determined on three $0.5 \mathrm{~m}^{2}$ square area subsamples for each grassland type.

Data analysis was conducted using the SAS statistical package (SAS Inst., 2002). Normal distribution of data was verified previously to statistical data comparisons, and analysis of variance (ANOVA) was conducted. Significant differences were considered at $p<0.05$.

\section{Results and discussion}

SOC ranged from 20.3 to $37.0 \mathrm{~g} \mathrm{~kg}^{-1}$ and from 15.4 to $32.5 \mathrm{~g} \mathrm{~kg}^{-1}$ before and after experimental fire, respectively, in soil covered by $H h$, and from 32.5 to $38.2 \mathrm{~g} \mathrm{~kg}^{-1}$ and from 38.3 to $49.1 \mathrm{~g} \mathrm{~kg}^{-1}$ before and after experimental fire, respectively, in soil covered by $A m$. The experimental fire did not have significant differences in SOC in both grassland types (Fig. 2). Similar to SOC results, $\delta^{13} \mathrm{C}$ was not affected significantly by fire. The average by time of $\delta^{13} \mathrm{C}$ values measured in $H h$ grassland was $-25.418 \pm 0.25 \%$ and $-25.161 \pm 0.40 \%$ in soil sampled before and after fire, respectively, while in $\mathrm{Am}$ grassland it was $-26.873 \pm 0.16 \%$ o and $-26.98 \pm 0.31 \%$ o before and after fire, respectively. Our results are in agreement with similar observations reported by other authors (Granged et al., 2011b) who found no change in SOC content before and after prescribed fire. The experimental fire has a moderate fire severity, similar to prescribed fire described by Granged et al. (2011b). The time of combustion was $12 \pm 2 \mathrm{~min}$ and $7 \pm 1 \mathrm{~min}$ for $H h$ and $A m$, respectively (Fig. 3). The maximum temperature measured at soil surface was around $480{ }^{\circ} \mathrm{C}$ in both grasslands. Temperatures over $200^{\circ} \mathrm{C}$ persisted for 5 and $3 \mathrm{~min}$ for $H h$ and $A m$, respectively. The burning time and intensity were low due to low amounts of fuel in both grasslands. Mediterranean environmental conditions involve high organic matter mineralization rates, and thus negligible amounts of litter biomass 
Table 1. Biomass composition (\% of dry biomass) of Hyparrhenia hirta (Hh) and Ampelodesmos mauritanicus (Am). Values in parenthesis are standard deviations. Abbreviations: $\mathrm{ADF}=$ acid detergent fibre, $\mathrm{NDF}=$ neutral detergent fibre.

\begin{tabular}{lcrrrrrr}
\hline Grassland & ADF & Cellulose & NDF & Hemicellulose & Ash & $\begin{array}{r}\text { Aboveground } \\
\text { biomass } \\
\left(\mathrm{Mg} \mathrm{ha}^{-1}\right)\end{array}$ & $\begin{array}{r}\text { C } \\
\text { Biomass } \\
\left(\mathrm{g} \mathrm{kg}^{-1}\right)\end{array}$ \\
\hline$A m$ & $6.91(0.58)$ & $37.72(1.58)$ & $73.03(2.65)$ & $23.99(1.32)$ & $4.02(1.10)$ & 4.76 & 43.8 \\
$H h$ & $5.98(0.68)$ & $34.00(1.20)$ & $72.01(1.53)$ & $28.26(1.76)$ & $4.34(1.49)$ & 11.60 & 45.8 \\
\hline
\end{tabular}

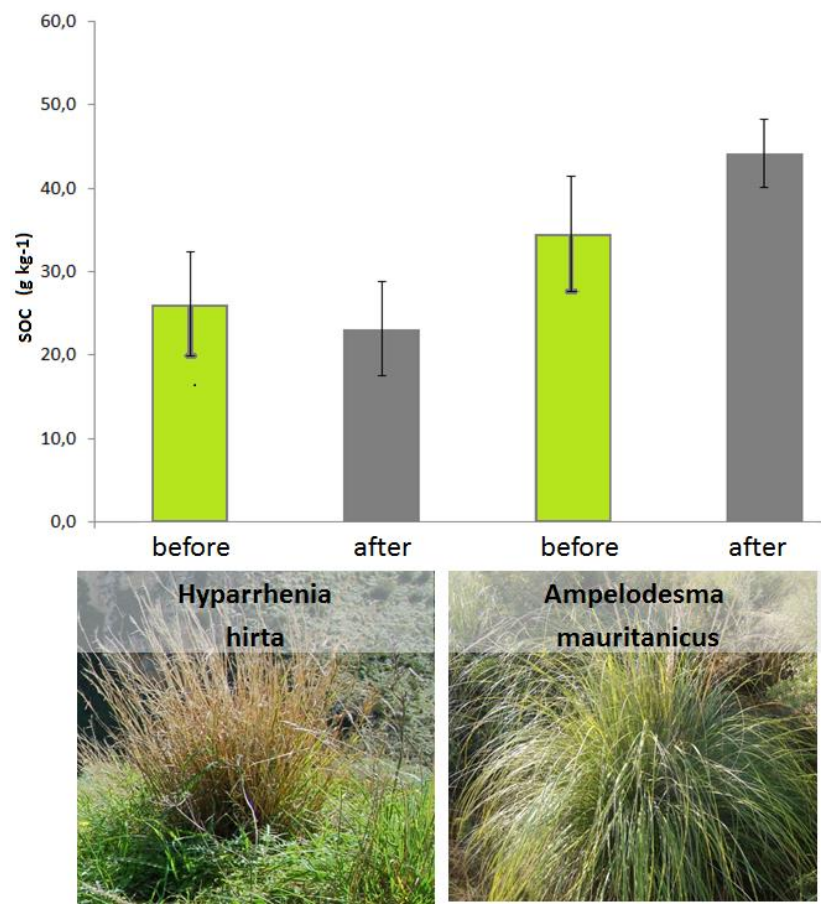

Fig. 2. Soil organic carbon before and after fire in Hyparrhenia hirta (Hh) and Ampelodesmos mauritanicus (Am) grassland.

stock. The low temperatures registered during low severity fires does not have important effects on SOC stock (Úbeda et al., 2005). The loss of organic carbon by burning can occur even at relatively low temperatures such as $200^{\circ} \mathrm{C}$, but total combustion is only observed at high temperatures 450 $500^{\circ} \mathrm{C}$ (De Bano et al., 1998). When comparing the two grasslands, the SOC amount and the effect of fire on SOC stock was contrasted. The lower SOC content was measured under $H h$ grassland, which also recorded the lower biomass yield. The above-ground biomass estimated is $4.76 \mathrm{Mg} \mathrm{ha}^{-1}$ and $11.60 \mathrm{Mgha}^{-1}$ of dry matter for $H h$ and $A m$ grassland, respectively.

Even if the SOC change before and after fire was not statistically significant, after fire SOC content decreased by $11.5 \%$ in $H h$ and increased by $27.9 \%$ in $A m$ grassland. The increase in SOC after fire could occur due to external inputs of charred material and ash, as is commonly observed in low severity fires due to incomplete combustion of fuel and organic mat-

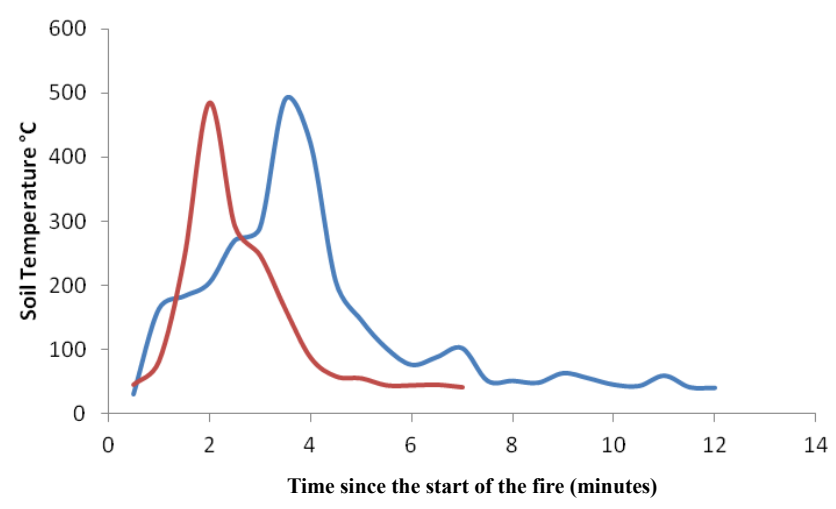

Fig. 3. Soil temperature during fire under Hyparrhenia hirta $(\mathrm{Hh})$ (blue line) and Ampelodesmos mauritanicus (Am) (red line) grassland.

ter. In particular, the burned material returns to soil as particles smaller than $2 \mathrm{~mm}$ in the form of ash, which are mixed in the top horizon, and which cause a net increase in SOC content (González-Pérez et al., 2004). The reason for the slight SOC increase after fire only in $A m$ grassland may depend on different characteristics of the two considered grasses. Firstly, Am biomass contains more lignin and cellulose than $H h$ biomass (Table 1), and thus more recalcitrant compounds that under low temperature do not completely volatilize. Secondly, Am has a densely caespitose habit: this feature impedes complete burning and favours the retention of incompletely burnt plant residues. The ash of $H h$ is, instead, lighter and quickly eroded by wind (Cerdà and Doerr, 2007). This is clear evidence that $H h$ grassland burned at higher severity, despite the similar temperatures observed. Previous studies observed that fire severity is different according to the burned species (Pereira et al., 2011). Thirdly, biomass of Am contains siliceous compounds that obstruct burning.

\section{Conclusions}

Data reported here confirm that the use of experimental fire to favour plant recovery in $H h$ and $A m$ grassland does not affect SOC stock, even if these grasslands have not burned for many years. Therefore it is possible to adopt the system of controlled burning to maintain grassland formations. 
Acknowledgements. This research was supported financially by the MIUR through the PRIN “CARBOTREES” project.

Edited by: A. Cerdà

\section{References}

Álvarez-Martínez, J., Gómez-Villar, A., and Lasanta, T.: The use of goats grazing to restore pastures invaded by shrubs and avoid desertification: a preliminary case study in the spanish cantabrian mountains, Land Degrad. Dev., doi:10.1002/ldr.2230, 2013.

Barberis, A., Dettori, S., and Filigheddu, M. R.: Management problems in Mediterranean cork-oak forests: Post-fire recovery, J. Arid Environ., 54, 565-569, 2003.

Bond, W. J., Woodward, F. I., and Midgley, G. F.: The global distribution of ecosystems in a world without fire, New Phytol., 165, 525-538, 2005.

Braun-Blanquet J.: Plant sociology, Mc Graw-Hill, New YorkLondon, 1932.

Briggs, J. M., Knapp, A. K., Blair, J. M., Heisler, J. L., Hoch, G. A., Lett, M. S., and McCarron, J. K.: An ecosystem in transition: Causes and consequences of the conversion of mesic grassland to shrubland, BioScience, 55, 243-254, 2005.

Brullo, C., Brullo, S., Giusso del Galdo, G., Guarino, R., Minissale, P., Scuderi, L., Siracusa, G., Sciandrello, S., and Spampinato, G.: The Lygeo-Stipetea class in Sicily, Annali di Botanica, 1-28, 2010.

Busso, C. A., Bonvissuto, G. L., and Torres, Y. A.: Seedling recruitment and survival of two desert grasses in the monte of Argentina, Land Degrad. Dev., 23, 116-129, doi:10.1002/ldr.1060, 2012.

Cerdà, A. and Doerr, S. H.: Soil wettability, runoff and erodibility of major dry-Mediterranean land use types on calcareous soils, Hydrol. Process., 21, 2325-2336, doi:10.1016/j.catena.2008.03.010, 2007,

Certini, G.: Effects of fire on properties of forest soils: a review, Oecologia, 143, 1-10, 2005.

DeBano, L. F., Neary, D. G., and Ffolliott, P. F.: Fire's Effects on Ecosystems, Wiley, New York, 1998.

Dickie, J. A. and Parsons, A. J.: Eco-geomorphological processes within grasslands, shrublands and badlands in the semi-arid karoo, south Africa. Land Degrad. Dev., 23, 534-547, 2012.

Díez-Garretas, B. and Asensi A.: Syntaxonomic analysis of the Andropogon-rich grasslands (Hyparrhenetalia hirtae) in the Western Mediterranean Region, Folia Geobotanica et Phytotaxonomica, 34, 307-320, 1999.

Fernández, I., Cabaneiro, A., and Carballas, T.: Organic matter changes immediately after a wildfire in an Atlantic forest soil and comparison with laboratory soil heating, Soil Biol. Biochem., 29, 1-11, 1997.

González-Perez, J. A., González-Vila, F. J., Almendros, G., and Knicker, H.: The effect of fire on soil organic matter-a review, Environ. Int., 30, 855-870, 2004.

Granged, A. J. P., Jordán A., Zavala, L. M., Muñoz-Rojas, M., and Mataix-Solera, J.: Short-term effects of experimental fire for a soil under eucalyptus forest (SE Australia), Geoderma, 167-168, 125-134, 2011a.
Granged, A. J. P., Zavala, L. M, Jordàn, A., and Barcenas-Moreno, G.: Post-fire evolution of soil properties and vegetation cover in a Mediterranean hethland after experimental burning: A 3-year study, Geoderma, 164, 85-94, 2011 b.

Kavdir, Y., Ekinci, H., Yüksel, O., and Mermut, A. R.: Soil aggregate stability and 13C CP/MAS-NMR assessment of organic matter in soils influenced by forest wildfires in Canakkale, Turkey, Geoderma, 129, 219-229, 2005.

Knicker, H.: How does fire affect the nature and stability of soil organic nitrogen and carbon? A review, Biogeochemistry, 85, 91118, 2007.

Kocyigit, R. and Demirci, S.: Long-term changes of aggregateassociated and labile soil organic carbon and nitrogen after conversion from forest to grassland and cropland in northern Turkey, Land Degrad. Dev., 23, 475-482, doi:10.1002/ldr.1092, 2012.

Kukal, D. S. S. and Bawa, S. S.: Soil organic carbon stock and fractions in relation to land use and soil depth in the degraded shiwaliks hills of lower himalayas, Land Degrad. Dev., doi:10.1002/ldr.2151, 2013.

La Mantia, T., Carimi, F., Di Lorenzo, R., and Pasta, S.: The agricultural heritage of Lampedusa (Pelagie Archipelago, South Italy) and its key role for cultivar and wildlife conservation, Ital. J. Agronom., 17, 106-110, 2011.

Li, X. L., Perry, G. L. W., Brierley, G., Sun, H. Q., Li, C. H., and Lu, G. X.: Quantitative assessment of degradation classifications for degraded alpine meadows (heitutan), sanjiangyuan, western china, Land Degrad. Dev., doi:10.1002/ldr.2154, 2012.

Mukhopadhyay, S. and Maiti, S. K.: Soil $\mathrm{CO}_{2}$ flux in grassland, afforested land and reclaimed coalmine overburden dumps: a case study, Land Degrad. Dev., doi:10.1002/ldr.1161, 2013.

Novara, A., Gristina, L., Bodì, B. M., and Cerdà, A.: The impact of fire on redistribution of soil organic matter on a Mediterranean hillslope under maquia vegetation type, Land Degrad. Dev., 22, 530-536, 2011.

Oba, G.: Effects of wildfire on a semidesert riparian woodland along the Turkwel river, Kenya, and management implications for turkana pastoralists Land Degrad. Dev., 2, 247-259, 1990.

Pausas, J. G. and Verdú, M.: Plant persistence traits in fire-prone ecosystems of Mediterranean basin: a phylogenic approach, Oikos, 109, 196-202, 2005.

Pereira, P., Bodi, M., Úbeda, X., Cerdà, A., Mataix-Solera, J., Balfour, V., and Woods, S.: Las cenizas y el ecosistema suelo, in: Actualización en métodos y técnicas para el estudio de los suelos afectados por incendios forestales, edited by: Cerdà, A. and Jordan, A., Càtedra de Divulgació de la Ciència, Universitat de Valencia, 345-398, 2010.

Pereira, P., Úbeda, X. Martin, D.A., Mataix-Solera, J., and Guerrero, C.: Effects of a low prescribed fire in ash water soluble elements in a Cork Oak (Quercus suber) forest located in Northeast of Iberian Peninsula, Env. Res., 111, 237-247, 2011.

Pereira, P., Cerdà, A., Úbeda, X., Mataix-Solera, J., Arcenegui, V., and Zavala, L.: Modelling the impacts of wildfire on ash thickness in a short-term period. Land Degrad. Dev., doi:10.1002/ldr.2195, 2013.

Pyne, S. J.: Fire: A Brief History, Seattle, WA, University of Washington Press, 2001.

SAS Institute.: The SAS System for Microsoft Windows, Release 8.2. SAS Inst., Cary, NC, 2002. 
Snyman, H. A.: Short-term response of rangeland following an unplanned fire in terms of soil characteristics in a semiarid climate of South Africa, J. Arid Environ., 55, 160-180, 2003.

Terefe, T., Mariscal-Sancho, I., Peregrina, F., and Espejo, R.: Influence of heating on various properties of six Mediterranean soils. A laboratory study, Geoderma, 143, 273-280, 2008.

Trabaud, L.: Man and fire: impacts on Mediterranean vegetation, in: Mediterranean-type shrublands, edited by: di Castri, F., Goodallm, D. W., and Specht, R. L., Elsevier, Amsterdam, 523537, 1981.

Úbeda, X., Lorca, M., Outeiro, L. R., Bernia, S., and Castellnou, M.: Effect of prescribed fire on soil quality in Mediteanean grassland (prades Mountains, north-east Spain), Int. J. Wildland Fire, 14, 379-384, 2005
Wang, W. Y., Wang, Q. J., Wang, Ch. Y., Shi, H. L, Li, Y., and Wang, G.: The effect of land management on carbon and nitrogen status in plants and soils of alpine meadows on the Tibetan plateau, Land Degrad. Dev., 16, 405-415, doi:10.1002/ldr.661, 2005.

Woube, M.: Effect of fire on plant communities and soils in the humid tropical savannah of Gambela, Ethiopia, Land Degrad. Dev., 9, 275-292, 1998.

WRB: World Reference base for soil resources 2006, 2nd edition.World Soil Resources Reports, No 103. Food and Agriculture Organization of the United Nation, Rome, 2006.

Yu, B., Stott, P., Di, X. Y., and Yu, H. X.: Assessment of land cover changes and their effect on soil organic carbon and soil total nitrogen in daqing prefecture, China, Land Degrad. Dev., doi:10.1002/ldr.2169, 2013. 